In his latest publication, however, (Jour. Min. Agric., June 1930, p. 227) he emphasises the similarity between leaf roll transmission by $M$. persicae and other plant virus diseases in which it is said that one, and only one, insect is capable of carrying the virus. $M$. persicae, he states, has a marked affinity for several potato viruses, especially for the leaf roll virus, whilst " other insects such as eapsid bugs, leaf-hoppers, and the remaining species of aphides, have failed to transmit the diseases". Here is evidence of the growing tendency referred to in the mind of at least one virus worker. Although proof is lacking, I think it quite probable that $M$. persicoe bears a more subtle relationship to leaf roll transmission than that of a mere mechanical agent, but this relationship, whatever it may be, would appear to be shared to some extent by $M$. circumflexus. So far from minimising the importance of $M$. persicce in leaf roll transmission, in my letter I attributed little or no importance to $M$. circumflexus as an active agent in spreading virus diseases.

Dr. Smith disagrees with my suggestion that $M$. circumflexus should prove of value in virus trans. mission studies, apparently because (1) it is not uncommon for the characteristic dorsal markings to be absent from specimens of $M$. circumflexus, and (2) this species is stated to be a poor transmitter of mosaic and to possess, in its saliva, a toxin which produces a 'false mosaic' in Solanaceous plants, including the potato. With regard to the first objection, it is obvious that the absence of the dorsal bands in occasional adults makes the task of detecting such apterous females of this species uncertain, but surely not more so than in other unmarked species, for example, $M$. persicce. Exceptional individuals need not be selected for use in artificial infestations, and any initial error in diagnosis can thus be obviated. The appearance of unmarked adults in the cages will, at least, raise a suspicion of admixture of species in the mind of the worker and will induce caution in interpreting results.

The suggestion that $M$. circumflexus possesses a toxin in its saliva is, if substantiated, of great importance and marks a definite advance in our knowledge of viruses. It will of course restrict the use of this species to special aspects of mosaic transmission, but it is difficult to see in what way the power to produce a false mosaic will impair the value of $M$. circumflexus in leaf roll transmission studies; and these studies, after all, formed the subject matter of my first letter.

T. WHITEHEAD.

University College of North Wales, Bangor, July 28.

\section{Flint Implements of Upper Palæolithic Age from Yorkshire.}

IN regard to Mr. Bromehead's objection (NATURE, July 5, p. 13) to my letter in the issue of June 7 , p. 858, it might perhaps dispel any misunderstanding that may have arisen in connexion with the same if I say that Messrs. Dewey and Bromehead, after they had investigated the sites under consideration last May, were unanimous in relegating Lamplugh's "Late Glacial Boulder Clay" deposit of Danes' Dyke to Late Pleistocene times, though, I was given to understand, they regarded it as a hill-wash formed under cold conditions rather than a boulder clay. In accordance with these opinions, Mr. Dewey afterwards supplied me with the wording for par. 2 of my letter in NATuRE of June 7 as representing both his and Mr. Bromehead's views concerming the age of the deposit they had been asked to examine.
As space cannot be spared in Nature for a full statement of the facts, I have given the details in a letter which I am circulating privately, and I am content to leave these to speak for themselves.

30 Southwick Street,

Hyde Park, W.2, July 7.

$$
\text { J. P. T. BURCHELL. }
$$

In answer to Mr. Burchell, it is inaccurate to say that I relegated Lamplugh's "Late Glacial Boulder Clay " deposit to Late Pleistocene times, since Lamplugh nowhere described the flint-bearing deposit by those words. In his paper on the Drifts of Flamborough Head (Quart. Jour. Geol. Soc., vol. 47, pp. $384-431$; 1891) he shows the deposit in question in only one of his fifteen sections, that at Danes' Dyke; he describes it as "a few feet of loamy stuff resembling a weathered Boulder Clay" and as "stony earth like weathered Boulder Clay", and in a generalised table includes it under the heading "Late Glacial Gravels, Brickearth, and Boulder Clay ". In all other sections Lamplugh ignores this deposit; he also omits to show any soil or subsoil. I personally am convinced that if Lamplugh were with us to-day he would class Mr. Burchell's deposit under some such heading, or use the more expressive Yorkshire term, 'muck'. In the memoir on Holderness, Clement Reid definitely classes the bed at Kelsey Hill, Burstwick, as Post-Glacial.

The report by Mr. Dewey and myself to the Director of the Geological Survey was made as favourable to Mr. Burchell's views as our opinions allowed. In his letter published in Nature of June 7, Mr. Burchell anticipated this report; he quoted the only words in any way favourable to his view and omitted to say that on the main question, whether the 'implements" are overlain by Boulder Clay, our decision was unfavourable. In his present letter he takes a similar course with regard to Lamplugh's published paper. I am therefore glad to know that his " full statement of the facts" has been circulated privately.

Geological Survey Office,

$$
\text { C. N. Bromehead. }
$$

14A Parliament Street, York.

\section{The Second World Power Conference at Berlin.}

IN his article in NATURE of July 19 on the Second Plenary World Power Conference in Berlin, Mr. H. Quigley has presented the results of the meeting in a somewhat wrong perspective. As a matter of fact, the constitution of the World Power Conference renders it almost impossible for immediate action to be taken such as he would suggest. The position is really as follows: a number of resolutions, some of which bear very directly upon the work of the Conference as a permanent organisation, were passed during the technical sessions, but in accordance with our unvarying practice, none of these resolutions was endorsed by the International Executive Council this year. They will be circulated to all the national committees, will be examined by a special sub-committee, and will come up for consideration and appropriate action at the next meeting of the Council, to be held in London at the time of the Faraday celebrations in September 1931. In other words, no exceptional treatment was accorded to the resolutions passed during the technical sessions this year.

On the other hand, the Intermational Executive Council, of its own motion, took a number of decisions of first-rate importance concerning the future "work of the Conference". Specific proposals were put forward by the Central Office or by national com-

No. 3172, VoL. 126] 